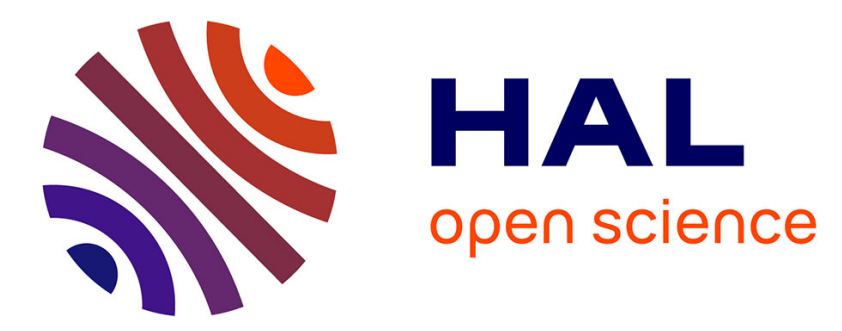

\title{
Grotius and Late Medieval Ius Commune on Rebellion and Civil War
}

\author{
Dante Fedele
}

\section{To cite this version:}

Dante Fedele. Grotius and Late Medieval Ius Commune on Rebellion and Civil War. Grotiana, 2020, Grotiana, 41 (2), pp.371-389. 10.1163/18760759-41020007 . hal-03094537

\section{HAL Id: hal-03094537 \\ https://hal.univ-lille.fr/hal-03094537}

Submitted on 4 Jan 2021

HAL is a multi-disciplinary open access archive for the deposit and dissemination of scientific research documents, whether they are published or not. The documents may come from teaching and research institutions in France or abroad, or from public or private research centers.
L'archive ouverte pluridisciplinaire HAL, est destinée au dépôt et à la diffusion de documents scientifiques de niveau recherche, publiés ou non, émanant des établissements d'enseignement et de recherche français ou étrangers, des laboratoires publics ou privés. 


\title{
Grotius and Late Medieval Ius Commune on Rebellion and Civil War
}

\author{
Dante Fedele, Chargé de recherche \\ Univ. Lille, CNRS, UMR 8025 - CHJ - Centre d'histoire judiciaire, F-59000 Lille, France \\ dante.fedele@univ-lille.fr
}

\begin{abstract}
This paper explores the presence of late medieval ius commune in Grotius's thought on the use of force in internal strife and war, based on De iure belli ac pacis (1625). To this end, it examines Grotius's use of ius commune sources, and considers some similar sources, which he does not actually cite, but which relate to his discussion. By clarifying Grotius's selection and use of ius commune sources, the paper intends to contribute to the achievement of a double aim: firstly, to determine the place of rebellion and civil war in De iure belli ac pacis, especially in relation to (external) war; and, secondly, to assess Grotius's approach to the two former issues, particularly with regard to the criteria by which a distinction between rebellion and civil war can be drawn, and to the effects of this distinction.
\end{abstract}

Keywords: Grotius, Ius commune, Rebellion, Civil War, Use of force

This paper explores the presence of late medieval ius commune in Grotius's thought on the use of force in internal strife and war, based on De iure belli ac pacis (1625). To this end, it examines Grotius's use of ius commune sources, and considers some similar sources, which he does not actually cite, but which relate to his discussion and can be fruitfully studied to broaden the scope of the analysis. By clarifying Grotius's selection and use of ius commune sources, the paper intends to contribute to the achievement of a double aim: firstly, to determine the place of rebellion and civil war in De iure belli ac pacis, especially in relation to (external) war; and, secondly, to assess Grotius's approach to the two former issues, particularly with regard to the criteria by which a distinction between rebellion and civil war can be drawn, and to the effects of this distinction.

One obvious starting point for this kind of investigation is Robert Feenstra's annotation of De iure belli ac pacis, which guides us neatly through the numerous sources cited by Grotius in his magnum opus, and enables the reader to appreciate the strong presence of ius commune jurisprudence. ${ }^{1}$ Feenstra also provided an overview of this subject in an

\footnotetext{
${ }^{1}$ See H. Grotius, De iure belli ac pacis libri tres, curavit B.J.A. De Kanter - Van Hettinga Tromp (1939), annotationes novas addiderunt R. Feenstra et C.E. Persenaire (Aalen: Scientia Verlag, 1993), hereafter cited as
} 
article which appeared in 1992, in which he demonstrates that Grotius sometimes had direct knowledge of the works he cited (although when writing De iure belli ac pacis he had no longer access to his personal library), and sometimes relied on second-hand references to medieval jurists (in the works of early modern scholars like Francisco de Vitoria, Alberico Gentili, Diego de Covarrubias and Fernando Vázquez de Menchaca, in particular). ${ }^{2}$ A ground-breaking study in the field - predating Feenstra - was Peter Haggenmacher's Grotius et la doctrine de la guerre juste, which is especially relevant to our analysis insofar as it focuses on war and the use of force, and - through careful analysis of both De iure praedae and De iure belli ac pacis - assesses the presence of ius commune authorities in these works. ${ }^{3}$ Subsequently, James Muldoon studied Grotius's use of medieval canon law in Mare liberum (1609), in order to show how the Dutch jurist, although he used the same source material as his Spanish predecessors, actually elaborated a different conception of the international order, criticising the idea of a trade monopoly based on papal donation, and asserting a basis for trade freedom in natural law. ${ }^{4}$ More recently, Robert Fredona has investigated the presence of late medieval jurisprudence in Mare liberum, insisting on the 'technical legal character' of this work and its scholarly apparatus, which includes 'an average of 2.25 mentions' of Roman, canon, and feudal law texts or commentaries per page, and features Bartolus de Sassoferrato and Baldus de Ubaldis as the most cited authors of that tradition. ${ }^{5}$

IBP. Translations are from H. Grotius, De jure belli ac pacis libri tres, transl. F.W. Kelsey (Oxford: Clarendon Press, 1925).

${ }^{2}$ See R. Feenstra, 'Ius commune et droit comparé chez Grotius: nouvelles remarques sur les sources citées dans ses ouvrages juridiques, à propos d'une réimpression du De iure belli ac pacis' (1992), in Id., Legal Scholarship and Doctrines of Private Law, 13th-18th Centuries (Aldershot: Variorum, 1996). See also Feenstra's Introduction to H. Grotius, Mare Liberum, 1609-2009: Original Latin Text [...] and Modern English Translation, ed. R. Feenstra (Leiden-Boston: Brill, 2009), pp. LVI-LIX. Further studies on Grotius by Feenstra are mentioned in A. Wijffels, 'Legal Scholastic and Humanist Influences on Grotius', in The Cambridge Companion to Hugo Grotius, ed. R. Lesaffer and J. Nijman (Cambridge: Cambridge University Press, forthcoming). On Grotius's working method, see M.J. van Ittersum, 'The Working Methods of Hugo Grotius: Which Sources Did He Use and How Did He Use Them in His Early Writings on Natural Law Theory?', in Reassessing Legal Humanism and its Claims. Petere Fontes?, ed. P.J. du Plessis and J.W. Cairns (Edinburgh: Edinburgh University Press, 2016), pp. 154-93.

${ }^{3}$ See P. Haggenmacher, Grotius et la doctrine de la guerre juste (Paris: PUF, 1983). See also Id., 'Grotius and Gentili: A Reassessment of Thomas E. Holland's Inaugural Lecture', in Hugo Grotius and International Relations, ed. H. Bull, B. Kingsbury and A. Roberts (Oxford: Clarendon Press, 1990), pp. 133-76.

${ }^{4}$ See J. Muldoon, 'Hugo Grotius, Medieval Canon Law and the Creation of Modern International Law', in Proceedings of the Ninth International Congress of Medieval Canon Law, Munich, 13-18 July 1992, ed. P. Landau and J. Mueller (Città del Vaticano: Biblioteca Apostolica Vaticana, 1997), pp. 1155-65, with further references. On the issue of free trade in Grotius's thought, however, see M. Somos, 'Open and Closed Seas: The Grotius-Selden Dialogue at the Heart of Liberal Imperialism', in Empire and Legal Thought. Ideas and Institutions from Antiquity to Modernity, ed. E. Cavanagh (Leiden/Boston: Brill/Nijhoff, 2020), pp. 322-61.

${ }^{5}$ See R. Fredona, 'Angelo degli Ubaldi and the Gulf of the Venetians: Custom, Commerce, and the Control of the Sea Before Grotius', in New Perspectives on the History of Political Economy, ed. R. Fredona and S.A. Reinert (Cham: Plagrave Macmillan, 2018), pp. 29-73: 30. Taking his lead from a reference found in H. Grotius, Mare liberum, p. 101 (p. 39 in the original edition of 1609), Fredona examines in particular Angelus de Ubaldis' consilium 290 (289 in some incunabula). Angelus's opinion deals with a clause of the peace treaty concluded in 1355 between Venice and Genoa, which regulated the freedom of navigation in the Adriatic and the Tyrrhenian, and was later also included in the treaty entered into by the two cities in 1381. Since Grotius, as already noted by Feenstra, copied the reference to Angelus from Giovanni Francesco Balbo's Tractatus de 
Grotius's categorisation of war in De iure belli ac pacis is well known. ${ }^{6} \mathrm{He}$ starts from a distinction between 'private war' (fought by private persons), 'public war' (fought by people invested with jurisdiction) and 'mixed war' (which is private on the one side, and public on the other). Public war is then divided into two sub-categories, i.e. 'formal (solenne)' on the one hand (which requires two conditions: a formal declaration of war, and the sovereignty of both belligerent parties) ${ }^{7}$ and 'less formal (minus solenne)' on the other (which is defined by the absence of either of these conditions). Internal strife and war fall under the category of 'mixed war' - they are, in fact, the only instance of mixed war that Grotius discusses (I.4). However, he also examines them in his analysis of 'less formal public war' (I.3). Actually, these two chapters seem to reflect different perspectives: in chapter 3 Grotius considers rebellion from the viewpoint of the public official (who has the authority to repress rebellion), whereas in chapter 4 he considers the same issue from the viewpoint of private persons (who normally enjoy no right of resistance). Internal strife and war are also touched upon in other passages of De iure belli ac pacis, including those on the right to send ambassadors (II.18.2.3), the right of burial (II.19.4), going to war on behalf of others (II.25.8), formal war (III.3.1), the right to appropriate objects captured in war (III.6.27), the rights over prisoners of war (III.7.5.3 and III.7.7), and the keeping of good faith with enemies (III.19.6-10).

This paper is divided into two parts. In the first, it deals with rebellion and its relation to the notion of war (bellum); in the second, it concentrates on civil war and - in particular some medieval antecedents of Grotius's conceptualisation of the two belligerent parties as two distinct gentes.

\section{Rebellion}

When he discusses less formal public war, in I.3.4, Grotius begins by presenting the opinion that not every public official has the authority to 'wage war for the protection of the people entrusted to his charge', since war can only be waged under the authority of the holder of the 'sovereign power in the state (summa in civitate potestatem) ${ }^{8}{ }^{8} \mathrm{He}$ refers to Plato's Laws (12.7), and to both Roman and canon law: lex Iulia maiestatis is cited, ${ }^{9}$ as are a constitution by Valentinian and Valens (from 364), and an excerpt from Augustin included in Gratian's Decretum. ${ }^{10}$ All of these sources state that the order to take up arms can only be issued by the princeps - a principle which is duly emphasised by the glosses to all these Roman and

\footnotetext{
praescriptione, Fredona uses this as a case-study about Grotius's 'second-hand erudition', see ibid., p. 62, note 23.

${ }^{6}$ See Haggenmacher, Grotius, pp. 529-37.

${ }^{7}$ On Grotius's notion of sovereignty, see ibid., pp. 537-47.

${ }^{8}$ Grotius, IBP, I.3.4.2, p. 96, transl. Kelsey p. 97.

${ }^{9}$ See Dig. 48.4.3.

${ }^{10}$ See Cod. 11.47.1, and c. 4, C. 23, q. 1, respectively.
} 
canon law passages. ${ }^{11}$ Two exceptions, however, are established: firstly, Grotius says, 'it is permissible for a public official, who has proper authority over a district, [...] to restrain by force a few that are disobedient, whenever there is no need of larger forces for the purpose, and danger does not threaten the state'. Note that a distinction between rebellion and civil war (the 'danger' which threatens the state) seems to be implied here, and based on a quantitative criterion; this point will be discussed later. Secondly, necessity is another exception to the laws requiring an order by the princeps to declare war: 'if the danger is so pressing that time does not permit consultation with him who has the supreme authority in the state, in that case also necessity will make an exception'. ${ }^{12}$ In order to support this assertion about the authority of subordinate public officials to put down an insurrection, Grotius cites Bartolus de Sassoferrato, Martinus Garatus Laudensis, Luis de Molina and Francisco de Vitoria. ${ }^{13}$ However, the only sources that specifically touch on this issue are actually Bartolus's comment on lex Ex hoc iure (Dig. 1.1.5), and a quaestio of Martinus Garatus's De iure belli. Bartolus attributed to Pierre de Belleperche and Guillaume de Cun the opinion that subordinate public officials can legitimately take up arms against their subjects without authorisation by the princeps both in a defensive war, and (if there is no princeps, or he has no de facto power) in an offensive war. ${ }^{14}$ Martinus Garatus, on the other hand - writing approximately a century after Bartolus -, stated that 'the princes and cities of Italy', since they recognised no superior, could wage war against either their subjects or external enemies, and went on to extend this principle to the situations in which the superior authority was absent. ${ }^{15}$

After establishing the right of subordinate officials to take up arms, Grotius wonders (in I.3.5) whether or not such war should properly be deemed 'public'. In this section he seems to adopt a more restrictive view than in the previous section, and to identify 'public war' with 'formal war', since - arguing against $16^{\text {th }}$-century authorities like Balthasar Ayala and Silvestro Mazzolini ${ }^{16}$ - he relies on late medieval jurists in declaring that, if the word

\footnotetext{
${ }^{11}$ See Ordinary gloss to Dig. 48.4.3, ad v. aut castra concesserit, ad v. delectumve, and ad v. comparuerit; Ordinary gloss to Cod. 11.47.1, ad v. movendorum; and Ordinary gloss to c. 4, C. 23, q. 1, casus and gloss ad v. principes (which refers to Cod. 11.47.1). Grotius also quotes lex Cornelia de maiestate (81/82 BC), according to which war cannot be waged without the order of the populus; on this lex see J.-L. Ferrary, 'Loi Cornelia de maiestate', in Lepor. Leges Populi Romani, ed. J.-L. Ferrary and Ph. Moreay (Paris: IRHT-TELMA, 2007), available at http://www.cn-telma.fr/lepor/notice39/ (accessed 30.07.2020).

${ }^{12}$ Grotius, IBP, I.3.4.3, p. 96, transl. Kelsey p. 98.

${ }^{13}$ See Grotius, $I B P$, I.3.4.3, p. 96 , note 5 with the additional notes by Feenstra for details.

${ }^{14}$ See Bartolus de Sassoferrato, In Primam Digesti Veteris Partem (Venetiis: Iunta, 1596), ad Dig. 1.1.5, fol. $7^{\mathrm{va}}$, n. 3. This opinion does not seem to have been explicitly stated by either Pierre de Belleperche, repetitio to Dig. 1.1.5 (ms Madrid, Biblioteca Nacional de España, 573, fol. $76^{\mathrm{vb}}-77^{\mathrm{ra}}$ ) or Guillaume de Cun ad Dig. 1.1.5 (ms Oxford, Bodleian Library, Canon. misc. 472, fol. $2^{\text {va }}$; ms Vienna, Österreichische Nationalbibliothek, Cod. 2257, fol. $65^{\mathrm{rb}}-65^{\mathrm{va}}$; ms Lucca, Biblioteca capitolare Feliniana, 373, fol. $2^{\text {va. }}$, and ms Olomouc, Zemský archiv v Opavě, pobočka Olomouc, C.O. 196, fol. $3^{\text {va }}$ ).

${ }^{15}$ See Martinus Laudensis, Tractatus de bello, in Tractatus illustrium in utraque tum pontificii, tum caesarei iuris facultate Iurisconsultorum [= Tractatus Universi Iuris] (Venetiis: Iunta, 1584), tomus XVI, quaestio 2, fol. $324^{\text {ra }}$. Martinus's Tractatus de bello is part of his Tractatus de principibus, written in Pavia and Siena in 1442-47 and dedicated to Filippo Maria Visconti.
}

${ }^{16}$ See B. Ayala, De iure et officiis bellicis, et disciplina miliari, (Duaci: Ex officina Ioannis Bogardi Typogr., 1582), I.2, fol. $8^{\text {r }}$, n. 9, who draws on M. Socini [junior], Consiliorum sive malis responsorum (Venetiis: apud 
'public' is understood 'as characterizing that which is done with due formality, [...] such wars are not public, for the reason that both the decision of the sovereign power and other conditions are necessary for the fulfillment of the legal requirements involved' ${ }^{17}$ Indeed, Bartolus had denied the 'public' character of the 'wars' waged by private persons to defend themselves or recover their properties, while Innocent IV had called them 'defense (defensio)' rather than 'war (bellum)', and had understood military actions against rebellious subjects as 'executio iurisdictionis vel iustitia' or 'executio iuris' rather than war. Nicolaus de Tudeschis (Panormitanus) had then talked of the war waged by subjects (including subordinate officials) without the authorisation of their superior as 'bellum improprie sumptum': this could be lawful or unlawful depending on whether or not there was a 'just cause' - the need to put down an insurrection, for example. ${ }^{18}$ It is noteworthy that, in chapter 6 of De iure praedae (1604-1608), Grotius had criticised these very medieval jurists when arguing that even (external) wars declared by subordinate officials - in cases of absence or negligence of the supreme magistrate - had to be termed 'public': he was then assuming that the requisite authority had been tacitly delegated to the subordinate officials concerned. ${ }^{19}$ In De iure belli ac pacis I.3.5 he no longer assumes this, and puts forward a stricter notion of 'public' war.

Philippum Iuntam, 1580), vol. III, consilium 68 , fol. $98^{\text {ra }}-98^{\text {rb }}$, n. 69 , and $78-80$; fol. $98^{\text {va }}$, n. 82 ; fol. $99^{\text {ra }}$, n. 94; and fol. $100^{\mathrm{vb}}$, n. 140-1. See also [Silvestro Mazzolini da Prierio], Sylvestrinae summae, quae summa summarum merito nuncupatur (Antverpiae: Ex officina Christophori Plantini, 1569), pars prima, ad v. Bellum, p. $90^{\mathrm{b}}$, n. 2.

${ }^{17}$ Grotius, IBP, I.3.5.1, p. 97 , transl. Kelsey pp. 98-9.

${ }^{18}$ See Bartolus de Sassoferrato, In Secundam Digesti Novi Partem (Venetiis: Iunta, 1596), ad Dig. 49.15.24, fol. 215 $5^{\text {ra }}$, n. 9; Innocent IV, Super libros quinque Decretalium (Francofurti ad Moenum: per Martinum Lechler, 1570; repr. Frankfurt am Main: Minerva, 1968), ad c. 12, X2.13, fol. $231^{\text {va-b }}$, n. 8; ibid. ad c. 29, X 2.24, fol. $288^{\text {va }}$, n. 5; and Abbas Panormitanus, Commentaria Secundae Partis in Secundum Decretalium Librum (Venetiis: [Società dell'Aquila che si rinnova], 1591), ad c. 29, $X$ 2.24, fol. 161 va , n. 9. On Innocent IV's comment ad c. 29, X 2.24 and executio iurisdictionis, see F.H. Russell, The Just War in the Middle Ages (Cambridge et al.: Cambridge University Press, 1975), pp. 175-6. A few lines below, Grotius also makes reference to a consilium by Franciscus Aretinus about the status of property taken in war, stating that the deprivation of property is not limited to formal war but also occurs in rebellions: see Franciscus de Aretio, Consilia (Ludguni: Iacobus Giunta, 1546), consilium 14, fol. $12^{\text {rb }}$, n. 9.

${ }^{19}$ See Haggenmacher, Grotius, pp. 145-6, and Hugo Grotius, De iure praedae commentarius, ms Leiden, University Library, BPL 917, chap. 6, fol. $28^{\mathrm{v}}-29^{\mathrm{r}}$ (hereafter cited as IPC; a critical edition of this manuscript by Jan Waszink is available at http://arkyves.org/view/DeIurePraedae, accessed 30.07.2020). This argument is restated in $I P C$, chap. 13 , fol. $128^{\mathrm{v}}-129^{\mathrm{r}}$, where Grotius maintains that the States Assembly of Holland had a right to wage war on the Portuguese, before going on to consider the justness of the Santa Catarina's capture as an act of 'public' war carried out by the Dutch East India Company (VOC). However, ibid., fol. 141 ${ }^{\mathrm{r}}$ Grotius says that "even if no order specifically concerned with prize had been issued, nevertheless, owing to the fact that both the Admiral of the fleet and the captains of the individual vessels had been granted jurisdiction by the state, these commanders would have been empowered - in the absence of other judges, and in defence of the rights of subjects as well as of their own authority - to impose punishment upon Portuguese offenders against that authority, and to seize the property of such offenders'. Grotius then refers again to the abovementioned comments by Bartolus, Innocent IV and Panormitanus to argue that 'this conclusion is especially tenable in the event that it is supported by a decree issued in advance; and in the present case such a decree was issued by the Admiral [dated December 4, 1602 marginal note] and rendered duly effective by the supreme naval council which assisted him in an assessorial capacity' (I used the translation by Gwladys L. Williams published in H. Grotius, Commentary on the Law of Prize and Booty, edited and with an Introduction by M.J. van Ittersum (Indianapolis: Liberty Fund, 2006), p. 429). 
The discussion on rebellion continues in chapter I.4 (on 'mixed war'), where Grotius excludes resistance against both the ruler who actually exercises his power in a despotic way, and the ruler who has no lawful title and is therefore a usurper (i.e. the two kinds of tyrannus described by Bartolus de Sassoferrato in his treatise De tyranno). ${ }^{20}$ There are some exceptions to this principle, the most interesting of which is that of the king who sets out to 'destroy' his people and, since he has thus proven himself to be 'an enemy of the whole people (hostis totius populi)', is considered to have renounced his kingdom. Grotius specifically refers to the king who rules over several peoples, and who 'may wish to have one people destroyed for the sake of another, in order that he may colonize the territory thus made vacant (ut colonias ibi faciat)'.${ }^{21}$ Drawing on a note by Jean Barbeyrac, Jules Basdevant and Peter Haggenmacher have pointed out that Grotius very likely considered this description to fit Philip II's attitude towards the United Provinces perfectly. ${ }^{22}$ A distinction thus emerges between individuals' right of resistance (which Grotius does not admit) and that of an entire people (which, under some circumstances, he does admit), suggesting again that mere rebellion and civil war can be quantitatively distinguished. Moreover, the fact that the king who sets out to destroy his people is called hostis totius populi seems to imply that there is little difference between collective resistance and a state of external public war. This argument appears to be in line with the view already expounded in De iure praedae - despite the much greater emphasis given to the justification of resistance in the latter work -, where Grotius attributes the right to resist the unjust ruler (i.e. Philip II) to magistrates that are vested with the 'supreme authority' (i.e. the Dutch States General), and ultimately considers war against Spain to be an instance of 'external war (bellum [...] externum)' rather than rebellion or civil $\mathrm{war}^{23}$.

\footnotetext{
${ }^{20}$ Grotius, IBP, I.4.1.3, p. 138, and I.4.15, pp. 159-60. See Bartolus de Sassoferrato, Tractatus de tyranno, ed. D. Quaglioni, Politica e diritto nel Trecento italiano. Il "De tyranno" di Bartolo da Sassoferrato (1314-1357) (Florence: Leo S. Olschki, 1983), quaestio VI, p. 185, 1. 206-9, and quaestio VIII, p. 196, 1. 447-9. Reference to Bartolus with regard to this twofold classification of tyranny is found in Grotius, IPC, chap. 13, fol. 135 (the passage including this reference is a later addition by Grotius).

${ }^{21}$ Grotius, IBP, I.4.11, p. 158, transl. Kelsey, pp. 157-8. For other exceptions, see Grotius, IBP, I.4.8-14.

${ }^{22}$ See J. Barbeyrac, in H. Grotius, Le droit de la guerre et de la paix, trad. J. Barbeyrac (Amsterdam: chez Pierre de Coup, 1729), p. 233, note 3, commenting on the passage quoted in the previous footnote: 'On a attribué ce dessein à Philippe II. Roi d'Espagne, par rapport aux Pais-Bas' (emphasis in original). This note is referred to by J. Basdevant, 'Hugo Grotius', in Les fondateurs du droit international, avec une introduction de A. Pillet (Paris: V. Giard \& E. Brière, 1904), p. 190, note 1, who in turn is cited by Haggenmacher, Grotius, p. 535.
}

${ }^{23}$ See Grotius, IPC, XIII, fol. $141^{\mathrm{r}}$. See also Haggenmacher, Grotius, p. 535-6 and - for De iure praedae - p. 147. In addition to $I P C$, there are other works previous to $I B P$ in which Grotius dealt with resistance: see $\mathrm{H}$. Grotius, Commentarius in theses XI: An early treatise on sovereignty, the just war, and the legitimacy of the Dutch revolt, ed. P. Borschberg (Bern et al.: Lang, 1994), which M.J. van Ittersum, 'Dating the manuscripts of De Jure Praedae (1604-1608): What watermarks, foliation and quire divisions can tell us about Hugo Grotius' development as a natural rights and natural law theorist', History of European Ideas 35 (2) (2009), 125-93: 143 considers to be a spin-off of $I P C$, XIII, dating probably to 1607-1609. See also Grotius's Theses LVI, ms Leiden, University Library, BPL 922, fol. $287^{\mathrm{r}}-290^{\mathrm{v}}$, which P. Borschberg, 'Grotius, the Social Contract and Political Resistance. A Study of the Unpublished Theses LVI', IILJ Working Paper 2006/7 (www.iilj.org) dates to either 1602-1605 or 1613-1615. Ibid., p. 62, note 181 Borschberg quotes Grotius's letter to Georg Michael Lingelsheim of 8 September 1617, which is also relevant to the issue of resistance, and on p. 64 , note 187 he cites another draft treatise by Grotius dealing with resistance against tyrants and preserved in ms BPL 922, De bello ob libertatem eligendo ex thesibus politicis M. Tullii, Lib. 9 ad Attic. Ep. 3. Grotius also strongly rejected individuals' and lower officials' right of resistance (except by mere disobedience to unjust laws) in his $D e$ 
In De iure belli ac pacis I.4, no specific reference is made to medieval ius commune authorities. That said, near the end of it, Grotius cites a passage from Thomas Aquinas's Summa theologiae - which he had already used in De iure praedae - in making yet another argument against the right of resistance. ${ }^{24}$ It is worth remarking that Bartolus, in his treatise De Guelphis et Gebellinis, had used the very same passage by Aquinas to argue in favour of rebellion - in the absence of a superior authority to which to resort - for the sake of public good. ${ }^{25}$ 'A tyrannical government - Aquinas said - is not just, because it is directed, not to the common good, but to the private good of the ruler, as the Philosopher states (Pol. 3.5; Eth. Nic. 8.10). Consequently there is no sedition in disturbing a government of this kind, unless indeed the tyrant's rule be disturbed so inordinately (sic inordinate), that his subjects suffer greater harm (maius detrimentum) from the consequent disturbance than from the tyrant's government. Indeed it is the tyrant rather that is guilty of sedition, since he encourages discord and sedition among his subjects, that he may lord over them more securely; for this is tyranny, being conducive to the private good of the ruler, and to the injury of the multitude'. ${ }^{26}$ While in De iure praedae Grotius had fully accepted Aquinas's line of argument, in De iure belli ac pacis he does not consider the possibility of rebellion for the public good, and simply states that, for Aquinas, 'the destruction of a government even though tyrannical is sometimes (interdum) an act of sedition'. ${ }^{27}$ This different use of Aquinas's passage in the two works provides a glimpse into Grotius's attitude towards sources and authorities: in fact, rather than being interested in interpreting them in their own context, or building up a consistent philosophical system, he appears to be guided by the need

\begin{abstract}
imperio summarum potestatum circa sacra (1614-1618, but published posthumously in 1648): see H. Grotius, De imperio summarum potestatum circa sacra, critical edition with Introduction, English translation and commentary by H.-J. van Dam (Leiden/Boston: Brill, 2001), III.6-8 and 14, pp. 212-7 and 227-8. Although only very few references to legal sources are found here, many theological references are the same which are found in IBP: see the editor's remarks, ibid., pp. 670-1 and 681-2. It is well known that Grotius wrote $I B P$ in France, and dedicated it to Louis XIII, who had welcomed him after exile: along with his wish to maintain good relations with James I, these were probably reasons that helped to make Grotius avoid extending the possibilities of (individual) resistance against sovereigns: see recently P.E. Vauthier Borges de Macedo, Catholic and Reformed Traditions in International Law. A Comparison Between the Suarezian and the Grotian Concept of Ius Gentium (Cham: Springer, 2017), pp. 121 and 273-82. The right of resistance is also denied in IBP I.3.8 (where Grotius criticises the notion of popular sovereignty), II.1.9, II.22.1 and III.7.7.
\end{abstract}

${ }^{24}$ Thomas Aquinas discussed the issue of rebellion (seditio) in S.Th. II ${ }^{\mathrm{a}}-\mathrm{II}^{\mathrm{ae}}$, quaestio 42.

${ }^{25}$ See Bartolus de Sassoferrato, Tractatus de Guelphis et Gebellinis, ed. Quaglioni, Politica, p. 139, 1. $157-64$.

${ }^{26}$ S.Th. II $^{\mathrm{a}}$-II ${ }^{\mathrm{ae}}$, quaestio 42, articulus 2, ad tertium, transl. the Fathers of the English Dominican Province (New York: Benzinger, 1947-1948), available at https://www.documentacatholicaomnia.eu/03d/12251274, Thomas Aquinas, Summa Theologiae \%5B1\%5D, EN.pdf (accessed 30.07.2020). In his previous commentary on Peter Lombard's Sententiae, dealing with the case of a tyrant who has acquired political authority by unlawful means, Aquinas had authorised rebellion without even referring to the 'greater harm' limit: see Scriptum super Libros Sententiarum, liber II, dist. 44, quaestio 2, articulus 2 ('Utrum Christiani teneantur obedire potestatibus saecularibus, et maxime tyrannis') and, on the issue, Reichberg, Thomas Aquinas, 123-7.

27 See Grotius, IPC, XIII, fol. 134 $4^{\mathrm{v}}-135^{\mathrm{r}}$ (Grotius does not cite Bartolus' De Guelphis et Gebellinis here, although he refers to it previously in the same chapter, fol. $129^{\mathrm{v}}$ ), and Grotius, IBP, I.4.19.3, p. 162, transl. Kelsey p. 162. 
to argue a specific point, or support a particular view, if necessary disregarding those sources' original meaning ${ }^{28}$.

The fact that Grotius - in general - denies the right of resistance to subjects does not stop him from allowing, in some cases, a third party to intervene in order to rescue them from the tyrannical acts of their ruler. ${ }^{29}$ In II.25.8 Grotius discusses the right to undertake war 'on behalf of the subjects of another ruler, in order to protect them from wrong at his hands', and he states that if some ruler 'should inflict upon his subjects such treatment as no one is warranted in inflicting, the exercise of the right vested in human society (ius humanae societatis) is not precluded': in this case, even though 'subjects cannot justifiably take up arms', it does not follow that 'others may not take up arms on their behalf [...]. The restriction, in fact, which prevents a subject from resisting, does not arise from a cause which is identical in the case of a subject and of one who is not a subject, but from the personal condition which is not transferred to others'. ${ }^{30}$ If one excepts classical sources, only two references to Vitoria's De Indis can be found in this passage, ${ }^{31}$ but elsewhere Grotius expounds a similar view relying on some medieval authorities. In II.20.40 he explicitly endorses Innocent IV's opinion that 'war may be waged upon those who sin against nature (qui in natura delinquunt)' ${ }^{32}$ and in I.5 he cites Innocent IV, Bartolus, Paulus Castrensis, Panormitanus, Jason de Mayno and Silvestro Mazzolini to argue in favour of service rendered to other men, if not due to other ties, at least by virtue of the 'common bond of human nature (humanae naturae communio)' ${ }^{33}$ It is worth pointing out that, among them, only Innocent IV had briefly touched on war waged 'causa pietatis vel humanitatis'; 34 Bartolus, Paulus, Panormitanus, and Jason de Mayno, on the other hand, had admitted the use of force in defence of someone else in the context of a discussion which concerned neither public war

\footnotetext{
${ }^{28}$ See H.-J. van Dam, 'Introduction', in H. Grotius, De imperio summarum potestatum circa sacra, p. 5.

${ }^{29}$ Grotius also states that faith should be kept with rebels, and talks about agreements reached between rebels and their sovereigns (Grotius, IBP, III.19.6-10).
}

${ }^{30}$ Grotius, IBP, II.25.8, pp. 596-7, transl. Kelsey pp. 583-4.

${ }^{31}$ See F. de Vitoria, De Indis, in Id., De Indis et de iure belli relectiones, ed. E. Nys (Washington, D.C.: Carnegie institution, 1917), sect. III, p. 264, n. 13 (reference to the 'titulus [...] amicitiae et societatis humanae'), and p. 265 , n. 15 (reference to Innocent IV's opinion that punishment can be imposed on someone 'pro peccatis contra naturam', which Grotius quotes in the passage cited in the next footnote).

${ }^{32}$ Grotius, IBP, II.20.40.4, p. 511, transl. Kelsey p. 506. See Innocent IV, Super libros, ad c. $8 X 3.34$, fol. $429^{\text {vb }}$ $430^{\mathrm{vb}}$, a comment which has been studied by J. Muldoon, Popes, Lawyers, and Infidels ([n.p.]: University of Pennsylvania Press, 1979), pp. 5-15 and passim. However, according to Innocent IV, the pope - being God's representative on earth - could punish the infidels who acted against natural law, or deprive of their jurisdiction infidel rulers who unjustly molested their Christian subjects, 'by judicial sentence (per sententiam)'. The thirdparty intervention imagined by Grotius obviously relies on different assumptions: see B. Straumann, Roman Law in the State of Nature. The Classical Foundations of Hugo Grotius' Natural Law (Cambridge: Cambridge University Press, 2015), pp. 213-7, according to whom 'Grotius' doctrine of a general natural right to punish' recognises 'certain grave violations of the natural law as being such as to affect the interests of all humankind, and vest[s] the right to punish these violations accordingly in every human being, and only derivatively in the sovereigns of commonwealths' (p. 215).

${ }^{33}$ Grotius, IBP, I.5.2.2, pp. 164-5, transl. Kelsey pp. 164-5.

${ }^{34}$ See Innocent IV, Super libros, ad c. $29, X 2.24$, fol. $288^{\text {rb }}$, n. 1 . The other comment of Innocent cited by Grotius (ibid., ad c. 12, X2.13) seems less relevant, except for a brief reference to the war made 'ad defensionem $[\ldots]$ aliorum' found on fol. $232^{\text {ra }}$, n. 9. 
in particular, nor the rebellion of subjects against their ruler, but rather people who generically suffered injustice. ${ }^{35}$ This principle had been applied to war by Johannes de Legnano and, based on the latter, by Silvestro Mazzolini, under the entry on 'war (bellum)' of his Summa, which gave it a particular significance in the context of the discussion of war. ${ }^{36}$

While he discusses the right to undertake war to support the rebellious subjects of another ruler, Grotius does not tackle the issue of whether or not someone can intervene in favour of another ruler and against the insurgents in a rebellion. This issue had certainly not been ignored in the ius commune tradition: Bartolus had raised it in his commentary on the constitutions Ad reprimenda and Quoniam nuper, possibly the most renowned late medieval legal source on resistance. ${ }^{37}$ Ad reprimenda and Quoniam nuper had been enacted by Henry VII in 1313 to provide a legal basis for his conviction of King Robert of Naples for rebellion against the empire. The emperor had sentenced Robert in absentia to be beheaded, and his land confiscated; pope Clement $\mathrm{V}$ had reacted by declaring the conviction invalid, both because Robert - who was domiciled in the terrae ecclesiae - could not be summoned from outside the borders of the empire, and because he had been stripped of his right to defend himself. ${ }^{38}$ In his commentary, Bartolus pondered on the legitimacy of rebellion and its consequences. Although in other writings he had admitted resistance against tyrants, he said that no cause could justify resistance against the emperor. ${ }^{39}$ In his view, the emperor was the supreme authority who legitimised all other powers, a principle which led to two consequences. Firstly, by definition the emperor could not himself be a tyrant. Secondly, as regards the consequences of rebellion, rebels against the empire (either private persons or

\footnotetext{
${ }^{35}$ See Bartolus de Sassoferrato, In Primam Digesti Veteris Partem, ad Dig. 1.1.3, fol. $7^{\text {ra }}$, n. 7-8: drawing on the Ordinary gloss, Bartolus first held that it was licit to defend 'consanguinei' based on 'affectio'. Then he admitted that other people ('ali[i] extrane[i]') could also be succoured, but suggested that before setting out to help them a request from their part ('mandatum') should be awaited. See also Paulus Castrensis, In Primam Digesti Veteris partem Commentaria (Lugduni: [excudit Ant. Blanc], 1585), ad Dig. 1.1.1.4, fol. $3^{\mathrm{vb}}$, n. 10-12; Abbas Panormitanus, Commentaria Primae Partis in Secundum Decretalium Librum (Venetiis: [Società dell'Aquila che si rinnova], 1591), ad c. 12, X2.13, fol. 184 ${ }^{\mathrm{va}}$, n. 18; Jason de Mayno, In Primam Digesti Veteris Partem Commentaria (Lugduni: [excudit Ant. Blanc], 1581), ad Dig. 1.1.3, fol. 6 ${ }^{\text {vb }}$, n. 28-29 ('ubicunque in aliqua lege [...] fit mentio de se, vel sua persona, vel sim, talia verba comprehendunt non solum propriam personam, sed etiam alios, quos circa se necessarios habet: puta uxorem, filios, \& similes [...]. Sed pulchrum dubium est, quid si sit extraneus, an liceat pro eo defendendo alium occidere? Bart[olus] \& communiter alij hoc concludunt quod sic, praesertim eo petente auxilium').

${ }^{36}$ See Johannes de Legnano, Tractatus de bello de represaliis et de duello, ed. Th.E. Holland ([n.p.]: Printed for the Carnegie Institution of Washington at the Oxford University Press, 1917), chap. 42, pp. 115-16, and [Silvestro Mazzolini da Prierio], Sylvestrinae summae, pars prima, ad v. Bellum, pp. 92 -93a, n. 8.

${ }^{37}$ See D. Quaglioni, “Fidelitas habet duas habenas”. Il fondamento dell'obbligazione politica nelle glosse di Bartolo alle costituzioni pisane di Enrico VII', in Origini dello Stato. Processi di formazione statale in Italia fra medioevo ed età moderna, ed. G. Chittolini, A. Molho and P. Schiera (Bologna: Il Mulino, 1994), pp. 38196.

${ }^{38}$ See W.M. Bowsky, Henry VII in Italy. The Conflict of Empire and City-State 1310-1313 (Lincoln: University of Nebraska Press, 1960), and K. Pennington, The Prince and the Law, 1200-1600. Sovereignty and Rights in the Western Legal Tradition (Berkeley et al.: University of California Press, 1993), pp. 165-201.

${ }^{39}$ See Bartolus de Sassoferrato, Consilia, quaestiones, et tractatus (Venetiis: [Iunta], 1596], Super constitutione 'Qui sint rebelles' [= 'Quoniam nuper'], ad v. rebellando, fol. $105^{\text {ra }}$, n. 1: 'Et advertendum est, quod in illo, qui rebellat contra principem, haec constitutio loquitur simpliciter, quasi contra eum non possit esse aliqua iusta causa resistendi'. Bartolus had admitted resistance against the tyrant, for example, in the passage cited supra, note 25. See Quaglioni, Politica.
} 
cities) lost ipso iure all rights derived from ius civile, and could be punished by anyone: if they were private persons, they could even be killed or enslaved, whereas if they were cities, they could be taken and plundered - although they could neither be destroyed, nor their population enslaved, without the consent of the emperor, to whom they belonged. ${ }^{40}$ Grotius did not raise the issue, nor did he cite Bartolus's commentary (in either De iure praedae or De iure belli ac pacis), although he must have been familiar with it, since it circulated both in early modern editions of Bartolus' work, and in those of the Corpus iuris civilis, where it was printed as the Ordinary gloss to the two constitutions. ${ }^{41}$ One may speculate on what Grotius might have written had he decided to elaborate on the issue. However, it is highly unlikely that he would have referred to Bartolus's commentary anyway, so much was the latter grounded in the notion of the emperor's universal sovereignty. Grotius, as is well known, strongly opposed this notion, discarding it as 'absurd' and drawing on Aristotle and jurists like Panormitanus, Jason de Mayno, Charles Dumoulin and Jacobus Menochius to oppose the universalism of Dante and Bartolus. ${ }^{42}$

In light of the above, it may be said that, in De iure belli ac pacis, Grotius chose to use only the best known ius commune sources on war, paying much less attention to the rich body of reflection on rebellion developed by both civil and canon lawyers. This drastic selection of his sources reveals Grotius's real interest, which lay in war, and the link between rebellion and the notion of war, rather than in rebellion per se. ${ }^{43}$

\section{Civil War}

We have already referred to certain passages in which Grotius draws a distinction between the rebellion of individuals and the uprising of entire populations. Civil war - unlike rebellion - is not simply an internal matter: it bears some similarity to external war, although it does not lead to all the latter's consequences. This limitation is made apparent when Grotius discusses the right to appropriate objects captured in war, and the right to enslave prisoners of war. ${ }^{44}$ In fact, in his view, the former right is 'so peculiar to a war that is formal (solennis) according to the law of nations that in other wars it finds no place', so that 'in wars between citizens, whether these be great or small, no change of ownership is made except by the authority of a judge'. ${ }^{45}$ As for the rights over prisoners of war, Grotius observes - relying on

\footnotetext{
${ }^{40}$ Bartolus, Consilia, fol. $105^{\text {va }}$, n. 13 , and fol. $105^{\text {vb }}-106^{\text {ra }}$, n. 23-4.

${ }^{41}$ In the fifth volume, called Volumen or Volumen parvum.

${ }^{42}$ Grotius, IBP, II.22.13, pp. 560-1. For the authorities to which Grotius referred in this passage, see Feenstra's notes 561e-5611, ibid., p. 999.

${ }^{43}$ The argument that Grotius's primary interest in De iure belli ac pacis was war has already been developed by Haggenmacher, Grotius, and A. Wijffels, 'De iure belli ac pacis libri tres. In quibus ius naturae \& Gentium: item iuris publici praecipua explicantur [...] 1625. Hugo Grotius', in The Formation and Transmission of Western Legal Culture. 150 Books that Made the Law in the Age of Printing, ed. S. Dauchy et al. (Cham: Springer, 2016), pp. 173-7: 175.

${ }^{44}$ Grotius, IBP, II.19.4.2, p. 456 can also be considered, where Grotius observes that 'legimus quidem in historiis exempla eorum qui insepulti abiecti sunt, frequentiora civilibus quam externis bellis'.

${ }^{45}$ Grotius, IBP, III.6.27, p. 705, transl. Kelsey p. 689, slightly modified (Kelsey translates 'solennis' as 'public'). This had already been a relevant issue in Grotius, $I P C$, fol. $141^{\mathrm{r}}$; ibid., fol. $14^{\mathrm{r}}$, in a note added at the
} 
Plutarch and Tacitus - that in civil wars 'on many occasions captives have been killed because they could not be reduced to slavery'. ${ }^{46}$

This approach to civil war was rooted in Roman law ${ }^{47}$. In the second half of the $14^{\text {th }}$ century, Baldus de Ubaldis had defined 'civil war (bellum civile)' as the war 'which a people begins against itself'. He had identified its causes in factional divisions within cities, quoting a 'wise Genoese' according to whom 'division in the city is the entry of the worm into the cheese'. Baldus had also distinguished this sort of war from external war ('bellum de gente ad gentem', as he called it elsewhere) by explaining that in a civil war captives do not become the slaves of their captors, nor do the postliminium or the fictio legis Corneliae apply, because this is not a genuine 'war' in the proper sense of the word. ${ }^{48}$ In the theological tradition, Isidore of Seville had distinguished external war (either just or unjust) from 'civil (civile)' and 'more than civil (plusquam civile)' war: 'civil war - he stated - occurs when factions arise among fellow-citizens and hostilities are stirred up, as between Sulla and Marius', whereas 'a more than civil war is where not only fellow-citizens, but also kinfolk fight - this was done by Caesar and Pompey'. ${ }^{49}$ However, he had not drawn a clear distinction between civil (and more than civil) war and insurrection, or sedition; on the contrary, he seems to have equated them when he wrote that 'as what is waged against external enemies is called "war", so "insurrection (tumultus)" is what is stirred up by civil sedition. Sedition (seditio) is a dissension (dissensio) of citizens, so called because they separate (seorsum ire) into different factions'. 50

bottom of the page Grotius had divided the bellum publicum into bellum civile and bellum externum, as opposed to bellum privatum.

${ }^{46}$ Grotius, IBP, III.7.5.3, pp. 708-9, transl. Kelsey p. 692 (the references to Plutarch and Tacitus were first added in the 1631 edition).

${ }^{47}$ See Dig. 49.15.21.1 cited infra, note 56.

${ }^{48}$ See Baldus de Ubaldis, In Sextum Codicis Librum Commentaria (Venetiis: [Società dell'Aquila che si rinnova], 1599; repr. Goldbach: Keip Verlag, 2004), ad Cod. 6.51.1, fol. 178 ${ }^{\text {ra }}$, n. 1 and 6: 'Nota, quod bellum civile est, quod in se populus movet [...]. Sed nunquid capti in isto bello fiunt servi capientium? Respondeo non: quia non sunt proprie hostes, sed partiales. Quia civitas divisa est in partes, ut ff. de cap. 1. si quis ingenuam, $\S$ in civibus [Dig. 49.15.21.1, on which see infra in the text]. \& ubi est ista divisio, accidit eodem modo, quo in arbore si scinderetur per medium, vel praescinderetur eius rami: quia cito desiccatur. In tali enim morbo abscinduntur nervi civitatis, idest magni cives. Unde civitati advenit spasmus, \& plerunque inducitur ad necessitatem tyrannidis, sicut experientia docet: quia imperi[t]um, \& ignobile vulgus non diu sustinet pressuras. Et dicebat quidam sapiens Ianuensis, quod divisio in civitate, est vermis ingressus in caseo. [...] Nota quod interfectus in bello moritur sui iuris \& habet haeredem absque aliqua fictione legis Corneliae: quia nunquam pervenit in potestatem hostium' (transl. J. Canning, 'Permanence and Change in Baldus' Political Thought', Ius commune 27 (2000), 290). See also Baldus de Ubaldis, In Decretalium Volumen Commentaria (Venetiis: [Iunta] 1595; repr. Turin: Bottega d'Erasmo, 1971), ad c. 10, X 1.9, fol. 97 ${ }^{\mathrm{vb}}$, n. 22: 'Aliud est bellum civile, quando cives eiusdem populi contra se ad invicem arma sumunt [...]. Quoddam est bellum de gente ad gentem [...]'.

${ }^{49}$ Isidore of Seville, Etymologiae, 18.1.2-4, transl. The Etymologies of Isidore of Seville, ed. S.A. Barney et al. (Cambridge: Cambridge University Press, 2006), p. 359a.

${ }^{50}$ Ibid. 18.1.6, transl. Barney et al., p. 359'. See L. Bussi, 'Echi dello jus belli romano nella dottrina canonistica della guerra giusta', Ius antiquum 1 (2004), 130-64: 140. Nor did Thomas Aquinas distinguish rebellion from civil war in S.Th. II ${ }^{\mathrm{a}}$-II ${ }^{\mathrm{ae}}$, quaestio 42, articulus 1, resp.: 'Bellum proprie est contra extraneos et hostes, quasi multitudinis ad multitudinem; rixa autem est unius ad unum, vel paucorum ad paucos; seditio autem proprie est inter partes unius multitudinis inter se dissentientes, puta cum una pars civitatis excitatur in tulmultum contra 
Although he touches on civil war in several passages of De iure belli ac pacis, Grotius never really dwells on this issue. Probably the most interesting insight on this matter is found in his chapter on the law of embassies. Here, after saying that the right to send and receive ambassadors in principle belongs only to sovereigns (because ius gentium applies between different nations: 'inter gentes est diversas'), ${ }^{51}$ Grotius makes an exception, and explains that 'in civil wars, however, necessity sometimes opens the way for the exercise of this right, though in an irregular fashion. Such a case will arise when a people has been divided into parts so nearly equal that it is doubtful which of the two sides possesses sovereignty [...]. Under such circumstances a single people is considered for the time being as two peoples (quasi duae gentes) ${ }^{52}$ Grotius just discusses a couple of examples here taken from Roman historical sources - and no legal authorities are mentioned. However, this specific issue had been debated in legal literature since the second half of the $16^{\text {th }}$ century, as demonstrated by the discussion engaged in by François Hotman, Pierre Ayrault, Alberico Gentili, and Jean Hotman (François's son) on the right of each faction, during civil war, to send ambassadors (i.e. agents enjoying full diplomatic status, including inviolability). All these scholars had admitted that factions in a civil war (not in a mere rebellion) enjoyed the rights established by ius gentium, and ius legationis in particular. ${ }^{53}$ Moreover, ways in which civil war contributed to the shaping of the conceptualisation of internal factions as independent universitates were already being recognised - and analysed - in the Middle Ages, with the struggles between rival factions in Italian cities from the $13^{\text {th }}$ century onwards. This analysis took place in the context of a broader debate (which culminated in Bartolus' treatise De Guelphis et Gebellinis) on the status of city-parties, in times of both peace and internal disorder. ${ }^{54}$

A quaestio discussed around 1273 by the Bolognese jurist Thomas de Piperata is a remarkable example of this debate, and is of particular relevance to any discussion of late medieval ius commune on internal strife and its legal consequences, in light of the

aliam'. See G.M. Reichberg, Thomas Aquinas on War and Peace (Cambridge et al.: Cambridge University Press, 2017), pp. 20-7.

${ }^{51}$ Grotius, IBP, II.18.2.1, p. 436: 'Sed primum sciendum est, qualecunque est hoc ius gentium de quo videbimus, ad eos legatos pertinere quos mittunt qui summi imperii sunt compotes inter se. nam qui extra hos legati sunt provinciales, municipales atque alii, non iure gentium, quod inter gentes est diversas, sed iure civili reguntur'. On the early modern debate about the right to send and receive ambassadors, see D. Fedele, Naissance de la diplomatie moderne (XIII ${ }^{e}$-XVII siècles). L'ambassadeur au croisement du droit, de l'éthique et de la politique (Baden-Baden and Zürich/St Gallen: Nomos and Dike Verlag, 2017), pp. 337-61.

${ }^{52}$ Grotius, IBP, II.18.2.3, p. 437: 'In bellis vero civilibus necessitas interdum locum huic iuri facit, extra regulam, puta cum ita divisus est populus in partes quasi aequales, ut dubium sit ab utra parte stet ius imperii: aut cum iure admodum controverso de regni successione duo decertant. nam hoc eventu gens una pro tempore quasi duae gentes habetur', transl. Kelsey pp. 439-40.

53 See D. Fedele, 'Ius gentium. The Metamorphoses of a Legal Concept (Ancient Rome to Early Modern Europe)', in Empire and Legal Thought, ed. E. Cavanagh, pp. 213-51. See also R. Kubben, “'We should not stand beside...". International legal doctrine on domestic revolts and foreign intervention throughout the early stages of the Dutch Revolt', in The Act of Abjuration: Inspired and Inspirational, ed. P. Brood and R. Kubben (Nijmegen: Wolf Legal Publishers, 2011), pp. 119-53.

${ }^{54}$ See P. Costa, 'Bonum commune e partialitates: il problema del conflitto nella cultura politico-giuridica medievale', in Il bene comune: forme di governo e gerarchie sociali nel Basso Medioevo (Spoleto: Fondazione Centro Italiano di Studi sull'Alto Medioevo, 2012), pp. 193-216, with further references. 
considerable analysis it devotes to the issue. At the time, Bologna was riven by factional discord, and Piperata - together with his fellow members of the Lambertazzi (i.e. Ghibellines) - would himself be exiled from the city in $1274 .{ }^{55}$ The text of his quaestio was partially edited (or rather summarised), in the $14^{\text {th }}$ century, by Albericus de Rosciate, who used it in his comment on Dig. 49.15.21.1. This excerpt from Ulpian deals with civil dissensions (civiles dissensiones), and says that in such situations, since 'the contest is not fought for the destruction of the respublica', 'those who go off to join one or other side are not counted as true enemies among whom the rights of captivity and postliminium apply'. ${ }^{56}$ This passage, with some others, is quoted in its entirety by Grotius in III.3.1.1 to argue that a formal war according to ius gentium can only take place between different peoples. ${ }^{57}$ At the beginning of his comment, Albericus de Rosciate remarked on the damage caused by civil strife, and defined the lex as 'golden and singular for the matter, which often occurs in miserable Italy, where constantly one party is expelling the other from cities and fortified places'. ${ }^{58}$ Then he summarised Piperata's quaestio, which deals with three issues: first, whether an expelled party can appoint a syndic (i.e. a representative), which would imply that it enjoys the status of a fully-fledged corporate body (universitas). Second, whether the members of an expelled party can be summoned by the city's podestà and whether or not he, if they ignore such a summons, can convict and punish them. And third, whether the intrinseci, if they are a minority of the people, still have the authority to represent the whole city, i.e. to alienate its property, or enter treaties on its behalf. To Piperata, the solution to all three issues depends on whether or not the expulsion was just. If an expulsion is motivated by a 'just cause (iusta causa)', the members of the exiled party are considered to be rebels who cannot constitute a separate universitas: they have no power to appoint a syndic and can be summoned, convicted and punished by the city's podestà; the intrinseci, on the other hand, retain the power to act on behalf of the whole city although they are a minority. If, however, the expulsion is not motivated by a 'just cause', the pars extrinseca constitutes a genuine universitas, the city's podestà is not entitled to summon its members, and the pars intrinseca

\footnotetext{
${ }^{55}$ The quaestio is preserved in two manuscripts in the Biblioteca Apostolica Vaticana: Arch. S. Pietro A. 29, fol. $138^{\mathrm{vb}}-139^{\mathrm{va}}$, and Chigi E.VIII 245, fol. $91^{\mathrm{ra}}-92^{\mathrm{va}}$ (where it is attributed to Alberto di Odofredo). These manuscripts have been extensively studied by M. Bellomo, I fatti e il diritto. Tra le certezze e i dubbi dei giuristi medievali (secoli XIII-XIV) (Rome: Il Cigno Galileo Galilei 2000), p. 559 for Piperata's quaestio, and Id., Quaestiones in iure civili disputatae. Didattica e prassi colta nel sistema del diritto comune fra Duecento e Trecento (Rome: Istituto Storico Italiano per il Medio Evo, 2008), pp. 92-3 for the edition of the casus. There is another quaestio by Piperata which deals with exiled city-parties, but I will not consider it here: see ms Arch. S. Pietro A. 29, fol. $101^{\mathrm{vb}}-102^{\text {ra }}$, which is also preserved in ms Erfurt, Universitätsbibliothek, CA. $2^{\circ} 227$, fol. $74^{\mathrm{v}}$; on this quaestio, see M. Bellomo, Quaestiones, p. 54 (with the edition of the casus). For an overview of Piperata's biography and work, see A. Padovani, 'Tommaso di Piperata (1230 ca. - ante 1282)', in Autographa I.2 Giuristi, giudici e notai (sec. XII-XV), ed. G. Murano (Imola: La Mandragora, 2016), pp. 43-4. On the political situation in Bologna in the late $13^{\text {th }}$ and early $14^{\text {th }}$ centuries, see S.R. Blanshei, Politics and Justice in Late Medieval Bologna (Leiden/Boston: Brill, 2010).

${ }^{56}$ Dig. 49.15.21.1, transl. A. Watson, The Digest of Justinian (Philadelphia: University of Pennsylvania Press, 1998), vol. 4, p. 405, slightly modified.

${ }^{57}$ Grotius, IBP, III.3.1.1, p. 646.

58 Albericus de Rosciate, In Secundam ff. Novi partem Commentarij (Venetiis: [Società dell'Aquila che si rinnova], 1585; repr. Bologna: Forni, 1982), ad Dig. 49.15.21.1, fol. 222 vb n. 1.
} 
(as it is a minority of the people) has no authority to bind the whole city. So, the criterion by which mere rebellion and civil war are distinguished is the just cause of the expulsion: if the expulsion is just, it is mere rebellion; if, on the contrary, it is unjust, Piperata says, 'it seems that two corporate bodies are made out of one (de una universitate videntur facte due)'. ${ }^{59}$ While the criterion of the just cause evidently differs from that which is used by Grotius and other early modern scholars, the latter expression used by Piperata is remarkably close to the 'quasi duae gentes' mentioned by the Dutch jurist, and provides us with a significant antecedent of Grotius's conceptualisation of the two parties in a civil war as two distinct gentes.

The 'just cause' criterion appears in the comments on lex Omnes populi made by Bartolus de Sassoferrato, Raynerius de Arsendis and Baldus de Ubaldis. In their discussion, they ask whether, after one party has been expelled from a city, the other can pass a statute that is binding on the entire people (including the members of the expelled party); and their answer depends on the justice, or otherwise, of the expulsion: if the expulsion was not motivated by a iusta causa, the new statute will only be binding on the party which remained in the city. ${ }^{60}$ Baldus adds another element to the discussion: if an expulsion is just, he says, 'jurisdiction remains in the hands of those inside the city because it adheres to the territory, and those inside possess the territory. [...] Those inside are a corporate body (universitas), and those expelled are separate individuals (singuli) '. ${ }^{61}$ The just cause criterion is combined here with the idea that jurisdiction adheres to the territory, and the intrinseci are still in control of the city's territory.

Elsewhere, Baldus reports an opinion of Raynerius de Arsendis about the capacity of the expelled party to acts that are binding on the whole city. The case discussed by Raynerius had taken place in Todi, and concerned the expelled Guelph party's recognition of the authority held by the Roman Church over the city. ${ }^{62}$ The jurist had considered the recognition to be invalid, since if the Guelphs had acted 'as separate individuals (ut singuli)' their action had no consequence for the city, and if they had acted 'collectively (ut universi)' their act was invalid, because their universitas was not licit. Baldus concurs with Raynerius, but makes an exception for the case in which 'the major part of the city were expelled, because then - he clarifies - it would make a licit corporation under the name of the majority and not that of a sect'. This passage is significant for our purposes, since here Baldus seems to rely on a quantitative criterion, not the just cause: in his view, the majority is held to

\footnotetext{
${ }^{59}$ Ibid., fol. $222^{\mathrm{vb}}-223^{\mathrm{rb}}$, n. 2-10 (for references to the original quaestio of Piperata, see supra, note 55).

${ }^{60}$ See Bartolus de Sassoferrato, In Primam Digesti Veteris Partem, ad Dig. 1.1.9, fol. 10 ${ }^{\text {ra }}$, n. 17; Raynerius Arsendis ad Dig. 1.1.9, in Albericus de Rosciate, In Primam ff. Veter. Part. Commentarij (Venetiis: [Società dell'Aquila che si rinnova], 1585; repr. Bologna: Forni, 1974), fol. $18^{\text {rb }}-18^{\text {va }}$, n. 40; and Baldus de Ubaldis, In primam Digesti Veteris partem Commentaria (Venetiis: [Società dell'Aquila che si rinnova], 1599; repr. Goldbach, Keip Verlag, 2004), ad Dig. 1.1.9, fol. 13 ${ }^{\text {va }}$, n. 34-6.

${ }^{61}$ Baldus de Ubaldis, In primam Digesti Veteris partem Commentaria, ad Dig. 1.1.9, fol. 13 ${ }^{\text {va }}$, n. 35, transl. J. Canning, The Political Thought of Baldus de Ubaldis (Cambridge et al.: Cambridge University Press, 1987), p. 130 .

${ }^{62}$ See Baldus de Ubaldis, In primam Digesti Veteris partem Commentaria, ad Dig. 3.4.1, fol. 193vb, n. 5. I have been unable to find Raynerius' original consilium.
} 
embody the universitas and thus to represent the city as a whole. ${ }^{63}$ In arguing this thesis, Baldus is drawing on Innocent IV and objecting to Bartolus's opinion: the latter had maintained that neither the expelled party nor the party within the city could alone submit the whole city to someone else, since neither had the power to represent it. ${ }^{64}$ Baldus argues to the contrary: the surrender 'is valid if it is done by the majority' albeit only 'to the prejudice of those making the surrender, [...] not of their superior' (meaning that if the city has a superior no surrender can be made at the expense of his rights). ${ }^{65}$

In these comments, moreover, both Bartolus and Baldus refer to another quaestio discussed in Bologna in the second half of the $13^{\text {th }}$ century. Its author was Lambertinus de Ramponibus who, unlike Thomas de Piperata, was a member of the Geremei (i.e. Guelph) party of Bologna; he nonetheless actively promoted peace with the Lambertazzi and in 1285, as a city councillor, endeavoured to have them return to Bologna. ${ }^{66}$ Despite the opposition of those who, like Dynus de Mugello, believed that parties did not have the status of an 'approved guild', Lambertinus stated that both Guelphs and Ghibellines were entitled to elect a syndic to make peace with one another. The issue under discussion here was therefore not the extent to which parties could legitimately act as representative of the whole city, but the possibility for each to elect a representative in order to make peace with the other within the same city. Bartolus remarks that this solution was actually observed in every-day practice. ${ }^{67}$

These examples show that interest in the nature and consequences of internal strife and war had already developed in the late medieval ius commune, which clearly distinguished between civil war (implying the recognition of both parties' legal personality) and rebellion (resulting in mere executio iurisdictionis against the insurgents, as stated by Innocent IV). Admittedly, the approach of late medieval jurists differed from that later adopted by Grotius, as did the criteria they proposed to distinguish the two situations whether they relied on the just cause, the adherence of jurisdiction to territory, or (like Grotius himself) on a quantitative criterion. Given the scant attention paid by Grotius to civil war,

\footnotetext{
${ }^{63}$ See Baldus de Ubaldis, In primam Digesti Veteris partem Commentaria, ad Dig. 3.4.1, fol. 193vb, n. 5 ('[...] nisi forte esset expulsa maior pars civitatis, quia tunc sub nomine maioris partis, non sub nomine sectae faceret collegium licitum iuxta no[tata] per In[nocentium IV] extra, de no. ope. nun. c. cum ex iniuncto [c. $2 X 5.32$ ]'), transl. Canning, The Political Thought, p. 154. See Innocent IV, Super libros quinque Decretalium, ad c. 2, X 5.32 , fol. $529^{\text {va }}$, n. 2.

${ }^{64}$ See Bartolus de Sassoferrato, In Secundam Infortiati Partem (Venetiis: [Iunta], 1596), ad Dig. 30.32.2, fol. $10^{\text {ra }}$.

${ }^{65}$ Baldus de Ubaldis, In Primam et Secundam Infortiati Partem Commentaria (Venetiis: [Società dell'Aquila che si rinnova], 1599; repr. Goldbach: Keip Verlag, 2004), ad Dig. 30.32.2, fol. $130^{\mathrm{ra}}-130^{\mathrm{rb}}$, transl. Canning, The Political Thought, p. 154.

${ }^{66}$ See G. Mazzanti, s.v. 'Ramponi, Lambertino', Dizionario Biografico degli Italiani, vol. 86 (Rome: Istituto dell'Enciclopedia Italiana, 2016), available at http:/www.treccani.it/enciclopedia/lambertinoramponi_(Dizionario-Biografico)/(accessed 30.07.2020).

${ }^{67}$ See the references to Bartolus and Baldus provided supra, notes 64 and 65 . I have been unable to find the original opinion of Lambertinus. As for Dynus de Mugello, a group of quaestiones authored by him are preserved in ms Vatican City, Biblioteca Apolistolica Vaticana, Borgh. 274; on fol. 86 ${ }^{\text {va }}$ there is a passage related to Dig. 30.32.2: 'In 1. si quis a filio $\S$ fi. [Dig. 30.32.2], questio fuit de facto an pars lambertinorum aut gibilinorum Bononie esset licita ad credendum seu constituendum syndicum, et dicebatur quod sic per hanc 1 [egem]. Sed valde parum facit, Dy[nus]'.
} 
and his almost complete avoidance of previous scholarship on the issue - again, his real interest seems to have been external war -, it is hard to say whether these discussions ever attracted his attention. Nevertheless, just as in the case of rebellion, his remarks on civil war can confidently be placed in the broader context of the ius commune tradition, and thus contribute to further our understanding of premodern and early modern scholarship on the use of force in internal strife and war. 